\title{
Assessing The Epic Framework: Guatemala
}

\author{
Marilyn M. Helms \\ Sesquicentennial Chair and Professor of Management \\ School of Business, Dalton State College, 650 College Drive, Dalton, GA 30720 \\ Email: mhelms@daltonstate.edu (Corresponding Author) \\ Steve LeMay \\ Associate Professor of Marketing and Economics \\ University of West Florida 11000 University Pkwy, Pensacola, FL 32514 \\ Email: slemay@uwf.edu \\ Michael J. Dwyer \\ 14 Avenida 41-13 Zona 12, Colonia Villa Sol, Guatemala, Guatemala, 01012 \\ Email: Dwyer.michaelj@gmail.com
}

\begin{abstract}
The EPIC framework was developed by Srinivasan, Stank, Dornier, and Peterson (2014) to assess supply chain readiness from Economic, Political, Infrastructural and Competence perspectives and was applied to 55 countries, a monumental undertaking. However, the framework needs further validation by applying it to other countries and using other raters. This research does both. Guatemala, for example, was not included in the 2014 EPIC ratings yet Guatemala is ideal for studying supply chain readiness given their participation and an anticipative role in CAFTA-DR (Dominican Republic-Central America Free Trade Agreement). Using Guatemala as a case, professionals in teams of three to six individuals in Germany and the United States applied the EPIC framework to judge supply chain readiness. The findings may serve as a model for businesses entering these sometimes operationally challenging markets. Areas for future research are included.
\end{abstract}

Key words: EPIC framework, supply chain readiness, Guatemala, economic, politics, infrastructure, competence

\section{INTRODUCTION}

Governments sign free trade agreements and in doing so, assign their countries a role or roles in multiple supply chains such as markets, as sources of natural resources, as sources of labor, as sources of technology, or as sources of financing. Developing nations usually serve as sources of labor and natural resources, while developed nations provide technology and finance. Both may serve as markets, although the benefits to developing nations may be small. Before leaping at the opportunities trade agreements offer, perhaps even before signing the agreements, government officials and business leaders should assess the readiness of each country in the agreement for its role or roles in supply chains. One way to assess readiness is by use of the EPIC framework (Srinivasan, Stank, Dornier, and Peterson, 2014). The EPIC framework was designed to assess supply chain readiness from Economic, Political, Infrastructural and Competence perspectives.
The EPIC framework chosen for this research has been fully applied to 55 countries and specifically addresses supply chain readiness. In this research, the authors apply the EPIC framework to Guatemala in a replication to determine if we can produce qualitatively similar results through Srinivasan et al.'s (2014) methods using different data. This is in keeping with recommendation by Peng, 2011 and Boylan et al., 2015; Ioannidis, 2015).Bettis, Helfat, and Shaver (2016) note that a replication uses as a reference point, a particular prior study and we followed this methodology replicating the procedures followed Srinivasan et al. (2014). We test the robustness of the original EPIC model in the context of an additional country with another set of raters. Guatemala was a recent signatory to the Central American Free Trade Agreement-Dominican Republic (CAFTA-DR), because the implementation of CAFTA-DR has been problematic in Guatemala, and because Guatemala was not included in the original EPIC research.

Bettis et al. (2016) term this methodology a "quasireplication" and note its importance for assessing generalizability as well as robustness of a model.Using Tsang and Kwan's (1999) taxonomy of the dimensions of replication, this research used the same design but with a different population and a different context. The goal is to determine how the EPIC model generalizes to new subjects and raters (Tsang and Kwan, 1999).

Business researchers have recently called for more replication and more application to validate frameworks (Krause, 2016) and he notes, "(P)romoting research for reproducibility requires a change from the status quo and represents an educational issue (p. 1). McCullough (2009), Crick et al., 20145; and Feigenbaum and Levy (1993) all suggest a cornerstone of research is verification through research and note it is an outright requirement of appropriate scientific practice. Reproducibility is a fundamental tenet of research and the authors all note that good science must be reproducible.

This research extended the original EPIC approach in several ways. First, one of the researchers has spent more than two years in the country, interviewing a variety of stakeholders in both formal and informal settings. This offers 
Helms et.al : Assessing The Epic Framework: Guatemala

48

a more qualitative context for the systematic research that replicates the original EPIC research as closely as possible. Second, this research used nine teams of young professionals in MBA classes in Germany and the United States(US) to assess the country. Third, these were consolidated into final assessments of Guatemala's supply chain readiness.

This research suggests that many of the social and political problems associated with the implementation of CAFTA-DR could certainly have been identified and might have been avoided if officials and business leaders had applied the results of the EPIC approach to assess Guatemalain reaching their decisions. Obviously, there is no way to know this for certain, but the results are potentially indicative. This research focused on answering two research questions:

1) How readily can the EPIC framework be applied by business professionals who are not necessarily experts in supply chain management?

2) Do teams produce consistent results when applying the EPIC framework to the same country?

The next sections of the paper briefly summarize the EPIC framework, describe Guatemala in terms of the EPIC framework analysis, and describe the methodology in greater detail. The final sections of the paper report the results of the research as answers to the two questions, draw conclusions about the value of the EPIC framework, and outline a path for future research. This analysis contributes to the literature by applying the EPIC approach to a new country and by using it in a classroom setting. This analysis becomes increasingly important as supply chains become more regional and as organizations recognize the problems associated with factor market rivalry (Ellram, Tate and Petersen, 2013; Ellram, Tate, and Feitzinger, 2013) and it also has implications for supply chains as other countries implement multi-national trade agreements. Recent research has also called for more pedagogical examples to enrich classroom discussions and improve students' comprehension of supply chains. This research answers that call (Xu, 2016; Helms et al., 2016).

\section{BACKGROUND LITERATURE}

\subsection{Guatemala and CAFTA-DR}

Many supply chain specialists agree there will be a move away from highly fragmented supply chains that span the globe in the future. It is suggested supply chains will move towards a greater reliance on regional production networks (Srinivasan, Stank, Dornier, and Peterson, 2014; Ellram, Tate and Feitzinger, 2013). The governments that crafted the Central American Free Trade AgreementDominican Republic (CAFTA-DR) intended that Guatemala play two keys roles in that agreement. First, they identified Guatemala as a potential market for agricultural equipment and technology, especially seed technology (Reeves, 2014). Second, they saw the northern mountains of Guatemala as a potential source of hydroelectric power (Lakhani, 2014). Guatemala has not adapted easily to either of these roles and since 2014 has seen major protests against Monsanto and against the hydroelectric development (Reeves, 2014; "Guatemala defies...," 2014; Lakhani, 2014).
Operations and Supply Chain Management 10(2) pp. 47 - 62 (C2017

Developing nations often have conflicts between improvement projects and indigenous cultures (Lewis, 2011). Some international agreements identify culture, indigenous culture in particular, as a right (Vadi, 2008), but also not a right (Fulmer, Godoy, \& Neff, 2008). In short, there is a complex relationship between the rules that govern the rights of the governments, organizations, and companies that promote economic projects and the rules that govern the rights of indigenous cultures; and the rules are so complex and multilateral that no one knows which rules apply and the application has become subjective (Fulmer et al., 2008).

By population, Guatemala is the largest country in Central America and has the potential to play a significant role in the supply chains supporting CAFTA-DR activity and development. Recent events suggest the corporations, government officials, and individuals who want to implement CAFTA-DR failed to do the essential background research, providinga better strategic approach. The EPIC model (Srinivasan et al., 2015) would likely reveal information essential to successful and likely peaceful implementations of these programs.

This research considers Guatemalan roles in CAFTADR as key to the success of CAFTA-DR, and also as an example of failing to do the essential groundwork associated with developing supply chains in a way that integrates indigenous supply chains and indigenous cultures. In this research, we show ways that the government officials and multinational managers could avoid conflicts along these essential supply chains and develop strong, supportive relationships with indigenous cultures. Using Guatemala as a laboratory, we applied the EPIC model (Srinivasan, et al., 2014) and ethnographic research to show how this analysis would better support less contentious approaches to development.

\subsection{The EPIC Framework}

The EPIC framework was developed as a way to evaluate global regions on their supply chain readiness by assessing four key areas (Economic, Political, Infrastructural and Competence) (Srinivasan, et al., 2014). In their original research, Srinivasan, et al. (2014) used a combination of publicly available secondary data and personal visits to the countries to make their EPIC assessments. This research follows a similar approach to assessing Guatemala, but with four major changes. First, we have researchers living in Guatemalaadding an ethnographic element to the research. Second, as Srinivasan, et al. (2014) developed the method for 55 countries, we focused on only one country. Third, we used outside raters to complete the assessment, and fourth, we added Guatemala to the list of countries originally assessed with the EPIC approach.

In the EPIC Framework (Srinivasan, et al, 2014), Economy is the wealth and resources in terms of production and consumption of goods and services targeted to a country or a specific geographic region. This category often includes gross domestic product (GDP), GDP growth rate, population, foreign direct investment (FDI), exchange rate stability, inflation, and balance of trade. The next category, Politics, includes state policy formation and enforcement and encompasses the ease of doing business, bureaucracy, corruption, corporate tax rates, tariff barriers, political risk, intellectual property rights, as well as the legal and 

regulatory framework. The third category, Infrastructure, is the physical and organizational structures for a society or enterprise and the services and facilities needed for a functioning economy such as the condition of highways, rail, air, sea, and inland transportation as well as energy. Competency is the supplier availability, access to technology and skilled labor and considers labor productivity, labor relations, education literacy, logistics competence, customs and security. These four EPIC categories provide an overview of a nation's or region's supply chains.

\subsection{EPIC Data for Assessing Guatemala}

This section provides an overview of Guatemala and specifically presents the indices and data for grading the supply chain readiness of the country. This follows the original methodology of Srinivasan, et al. (2014).

The ethnic population of Guatemala as a whole is Mestizo and European 59.4\%, K'iche 9.1\%, Kaqchikel 8.4\%, Mam 7.9\%, Q'eqchi 6.3\%, other Mayan 8.6\%, indigenous non-Mayan $0.2 \%$, other $0.1 \%$ (CIA World Factbook, 2015). Mestizo is mixed Amerindian-Spanish and in local Spanish called "Ladino."

Srinivasan et al. (2014), in their development of the EPIC framework, used information from in-depth studies conducted by respected and well-established organizations like the World Bank, the US Central Intelligence Agency (CIA), the World Trade Organization, The Economist, the United Nations Conference on Trade and Development (UNCTAD), and the World Economic Forum. To the extent data were available, the authors replicated the approach in this study using eight teams of international business professionals, replicating the EPIC framework prior to adding the ethnographic information. This approach provides invaluable insight and a solid foundation for this research. With the quantitative data, we have included data from the US and other countries to better position Guatemala's status in the context of key macroenvironmental measures. We summarize our discussion of Guatemala by comparing our assessment of the country to Srinivasan et al.'s (2014)assessment of Central and South America. Table 1 identifiesthe EPIC variables and their data sources from Srinivasan et al.'s(2014) study. The next section of the research examines each EPIC variable for Guatemala and replicates as closely as possible the EPIC assessment methodology. Each variable is discussed in the context of the authors' extensive interviews during the ongoing three-year time period spent in Guatemala.

Table 1. EPIC Variables and Sources

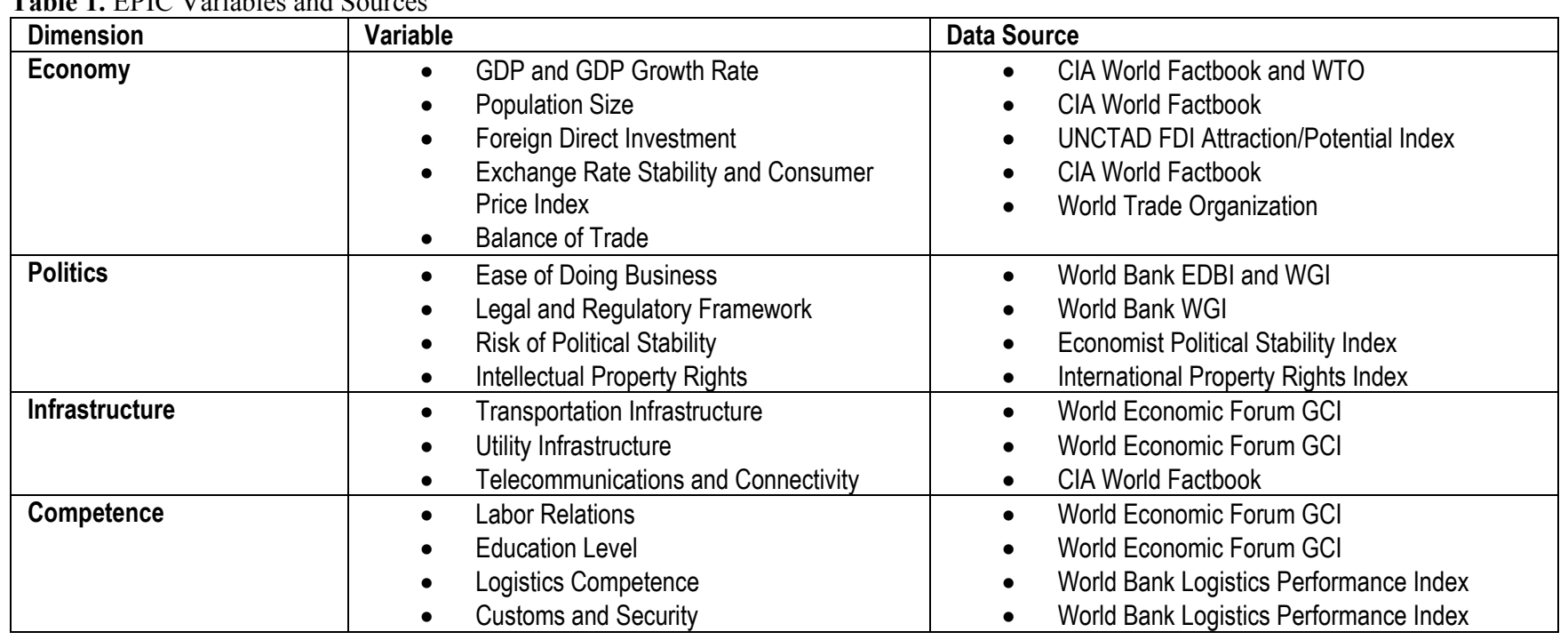

Source: Srinivasan, Mandyam; Theodore Stank, Phillipe-Pierre Dornier, and Kenneth Peterson, (2014) Global Supply Chains: Evaluating Regions on an EPIC Framework - Economy, Politics, Infrastructure, and Competence. New York: McGraw Hill.

\subsection{Economy: Guatemala}

With a population of 16.66 million (http://countrymeters.info/en/Guatemala), Guatemala is the largest country in Central America. Its Gross Domestic Product (GDP) reached $\$ 63.91$ billion in 2015 based on the most current CIA World Factbook (2015) dataand continues to grow at a rate of $4.1 \%$. GDP per capita is $\$ 7,700$ (PPP), ranking Guatemala $141^{\text {st }}$ of the 228 countries ranked in the CIA World Factbook (2015). UNCTAD uses its Foreign Direct Investment (FDI) index to compare potential foreign investments to actual foreign investments. On this basis, Guatemala fell slightly below expectations. Guatemala falls into a category of FDI inflows between \$1 billion and \$4.9 billion. In 2011 , FDI was less than $0.11 \%$ of GDP, or $\$ 985$ million. This figure rose to slightly above \$1 billion in 2012 and 2013, the most recent data available.

In 2013, the Guatemalan economy was comprised of $62.7 \%$ services, $23.8 \%$ manufacturing, and $13.5 \%$ agriculture. Agricultural growth is limited by the dependence of the economy on water resources. Given the country's lack of infrastructure for irrigation, recent droughts have restricted investment in agriculture. Guatemala imports $\$ 16.7$ billion in goods, primarily fuel, machinery, and transportation equipment and exports $\$ 10.3$ billion, primarily commodities. Guatemala's largest trading partner for both imports and exports, by far,is the United States,although Guatemala imports some goods from China, but exports nothing to China. 
Inflation has ranged from $3.8 \%$ and $4.4 \%$ over the last three years. Exchange rates with the US dollar have ranged between 7.6 and 8.2 Guatemalan quetzals per dollar. Recently the exchange rate stabilized at 7.8 Guatemalan quetzals per US dollar. While the currency is stable, a lower inflation rate would aid in attracting more international investors.

Estimates of unemployment hover around $4 \%$, but these figures can be deceptive. Many areas have children and adults of all ages selling artisanal goods or participating in low-entry cost entrepreneurial ventures such as offering shoe shines on street corners. It isopen to debate whether the people participating in these micro-enterprises are considered employed and whether the employment is considered full- or part-time.

According to official figures, 54\% of Guatemala's people live below the poverty line. A typical Guatemalan worker makes less than minimum wage and indigenous workers make evenless. Over $60 \%$ of workers in Guatemala earn less than the published minimum wage (Guatemala Times, November 11, 2011). The minimum wage worker earns approximately $\$ 3,000$ a year, but the average salary in the private sector is about $8 \%$ less at $\$ 2,784$ (National Institute of Statistics of Guatemala, 2011). For indigenous workers, it is even lower at $\$ 1,938$, about $23 \%$ less than the national average (National Institute of Statistics of Guatemala, 2011). These figures vary with the exchange rates, and inconsistencies appear to be inevitable.

The Guatemalan minimum wage distinguishes between garment workers and others. For garment workers the minimum wage is $\$ 7.61$ a day; for everyone else it is $\$ 8.16$ a day. But neither wage would have a significant impact on the national poverty rate, officially $54 \%$. The United States Department of State's 2011 Country Report on Human Rights Practices found if an employee in Guatemala worked 365 days a year, they would earn approximately $\$ 2,978$ per year, but this would not cover a minimal food, housing, and health care budget. The Human RightReport estimated the cost for a minimal standard of living in Guatemala to be $\$ 6,840$, more than twice the stated minimum wage. If both parents worked 365 days a year at minimum wage, they still would not earn this amount according to the US Department of State (2015).

Spanish is the official language of Guatemala, but the government recognizes 23 indigenous languages. About $60 \%$ of the population speaks Spanish, but many Guatemalans in rural areas speak only indigenous languages, so they remain outside the mainstream of Guatemala and the global economy.

\subsection{Politics: Guatemala}

Guatemala rose substantially in the ranking for ease of doing business, moving from $93^{\text {rd }}$ in 2013 to $79^{\text {th }}$ in 2014 . The Ease of Doing Business Index measures variables such as ease of starting a business, ease of paying taxes, and ease of obtaining construction and other permits. Guatemala improved on all three areas, primarily by moving the process on-line and allowing registration with multiple government agencies simultaneously. Guatemala ranks high on obtaining credit, registering property, and securing electricity, but resolving conflicts, protecting investors, resolving insolvency, improve trading across borders, and
Operations and Supply Chain Management 10(2) pp. 47 - 62 (C2017

actually starting a business remain problematic. Most of the problems stem from the country's slow, bureaucratic processes. For example, it takes 1,402 days (about 3.84 years) to enforce a contract and costs $26.5 \%$ of the claim to do so. The OECD average is 529 days and $21 \%$ of the claim. Guatemala's slow process is almost double the time for contract enforcement in Latin America and the Caribbean, although the cost of enforcement is lower (World Bank, 2015).

Guatemala ranks about average for all countries on the quality of its regulations, but well below average on the rule of law, control of corruption, and government effectiveness. Guatemala ranked $61^{\text {st }}$ on The Economist's Political Stability Index. In this index, the higher the overall score, the better; Guatemala's score of 6.6 was based on an underlying vulnerability score of 6.3 and an economic distress score of 7.0. For perspective, Russia had a score of 6.5, with underlying vulnerability at 5.0 and economic distress at 8.0. These scores were from 2009 to 2010 , so the economic distress scores reflect the Great Recession. At this point, the US ranked $110^{\text {th }}$ because of the economic distress score, at 8.0 , but with an underlying vulnerability score of 2.5 (The Political Instability Index. 2009-2010).

Guatemala's overall score on the property rights index was poor, but the scores come from mixed circumstances. In registering property, Guatemala scored $9.1\left(24^{\text {th }}\right.$ out of the 130 countries ranked), but on copyright protection, the country scored 2.1 (ranking $82^{\text {nd }}$ of the 130 countries). Guatemala's scores averaged 6.3 on patent protection and intellectual property rights, but lower on judicial independence, rule of law, political stability, and control of corruption. Overall, the country ranked $90^{\text {th }}$ of 130 in the world (World Economic Forum, 2015).

Members of the World Trade Organization (WTO) in formulating or amending their laws and regulations, may adopt measures necessary to protect public health and nutrition and to promote the public interest in sectors of vital importance to their socio-economic and technological development, provided that such measures are consistent with the provisions of this Agreement (TRIPS, 2009 athttps://www.wto.org/english/tratop_e/trips_e/t_agm2_e.ht m). The Trade-Related Aspects of Intellectual Property Rights (or TRIPS), under the World Trade Organization, permits all members, including those with great sectoral disparities, to "carefully tailor the country's protection to local needs" (TRIPS, 2009). In Guatemala, this is meaningful because of the hydroelectric dam planned under the auspices of CAFTA-DR. The dam is intended to supply hydroelectric power to Guatemala and other countries in Central America, however, not everyone in the area favors the development of this dam, and under TRIPS, individual governments are not necessarily obligated to adopt every provision of the agreement (World Trade Organization, 2015).

Emilia Xico, age 37, a mother of seven and member of the Margaritas ancestral committee, said: "For us, development means respecting and protecting Mother Earth, so that our children will always have food and water. This dam is not development for us. We are conscious of the things we don't have and, of course, I want better education for my children - that is our right - but we won't trade our territory and sacred natural resources. That's all we have." (“Guatemala's Indigenous Community..., 2014). 


\subsection{Infrastructure: Guatemala}

Guatemala infrastructure concentrates arounds its ports and large cities, particularly Guatemala City. Infrastructure in other regions of the country is limited. Guatemala's has a 12,795 kilometer (3,519 mile) highway network, albeit in poor condition. The country has low electricity and telephone density, yet the use of cell phones is growing rapidly and privatized electricity distribution has helped to increase availability. Concentration of television stations and newspapers are also in Guatemala City. Ports of Champerico, Puerto Barrios, and San Jose manage most of the country's exports. La Aurora Airport is the only national airport with capacity for both freight and passengers ("Guatemala - Infrastructure..., n.d.). For practical purposes, Guatemala has no functioning railroad (Allen, n.d.).

In October 1996, the Congress of Guatemala voted to reform the electric power market, allowing the private sector to participate in a number of projects. The reforms gave private companies unrestricted access to the power grid, distributors, and wholesale customers, and provided for a general unbundling of generation, transmission, and distribution. Privatization of state-owned electric companies has begun with the selling of the state distribution company, EmpresaElectrica de Guatemala (EEGSA), and the primary generating company, Instituto Nacional de Electrificacion (INDE). On July 30, 1998, 80\% of EEGSA, which provides power to more than 500,000 customers in Guatemala City and two neighboring provinces, was sold for $\$ 520$ million, far higher than had been expected by Guatemalan officials, to a consortium of Spain's Iberdrola Energia (49\% share), US-based Teco Energy (30\%), and Portugal's Eletricidade de Portugal (21\%). Overall, EEGSA (now called DECASA) distributes $70 \%$ of Guatemala's power, with INDE and 14 smaller municipal distribution companies (plus a few private generation facilities partially owned by US companies Enron, Teco, and Constellation Energy) accounting for the remaining 30\%. Immediately following the successful sale of EEGSA/DECASA, Guatemala kicked off the sale of INDE as well. In October 1997, INDE was divided into three separate companies, with INDE becoming a holding company (World Bank, 2003).

Guatemala has challenges with fixed-line telecommunications infrastructure. The fixed-line density is one of the lowest in the region. This means that barcoding and other form of basic data-capture for IT-enabled supply chains is available in major metropolitan areas like Guatemala City but also non-existent in other areas of the country (Guatemala - Telecoms...," n.d.).

\subsection{Competence: Guatemala}

Logistics competence covers four principal areas: (1) labor relations, (2) education level, (3) logistics competence, and (4) customs and security (Srinivansan, et al., 2014). Guatemala does well in labor relations, but earns mixed scores through the rest of the categories. This section compares Guatemala to the US, Mexico, Costa Rica, and Panama. The US is included to provide a broader perspective, while Panama and Costa Rica, nearby countries, are covered in the original EPIC analysis.

\subsubsection{Labor: Availability, Productivity, and Relations}

Guatemala boasts a young workforce, younger by far than its neighbors to the North, the US and Mexico. The median age in Guatemala is 21, compared to 37.6 for the US and 28 for Panama, 30 for Costa Rica, and 27.3 for Mexico (CIA Worldfactbook.com). This youth appears to be simultaneously an advantage and a disadvantage for the workforce. It means that there are a large number of people moving into the workforce, but it also means that their skill level is relatively low; they are still untrained and unskilled.

Primary school enrollment is low relative to the rest of the world, still $92.8 \%$, but the quality of education at this level is seen as low. Secondary education enrollment is $65.1 \%$, also among the lowest in the world (World Economic Forum Global Competitiveness Index, 2015). Illiteracy remains a problem, but more in the rural areas than in the economic centers like Guatemala City. Enrollments and education quality are also higher in urban areas.

Guatemalan high schools have three major tracks: general education, bilingual secretary, and bookkeeping/accounting. Few enroll in the general education track, which would be considered the curriculum for a typical high school diploma. Most males who enter universities have high school diplomas in accounting, while many working women have diplomas as bilingual secretaries. This may help to explain the relatively high quality of the management schools (World Economic Forum Global Competitiveness Index, 2015).

Guatemala ranks in the top third of the world in the quality of management schools, the quality of staff training, and the local availability of specialized research and training (World Economic Forum Global Competitiveness Index, 2015). Guatemala also has one of the lowest net migration rates in world at minus two $(-2)$, ranking it at $166^{\text {th }}$. That means that twice as many people leave the country as come in, although this does not reflect the major presence of foreign aid workers in some areas of the country.

Wages tend to be low, with an official minimum wage in Guatemala at about \$10 USD a day, but that wage requirement is often violated, especially in rural areas. Wages for agricultural workers are officially about $10 \%$ lower than for other workers, but in practice they are even lower. Also, Guatemala has a high rate of child employment. The official unemployment rate is $4.1 \%$ (CIA Worldfactbook.com, 2015); people are counted as employed if they worked for pay at least one hour during the prior week (Guatemalan Central Bank, 2015).

Guatemala ranks high in labor relations. Guatemala ranks in the top 25 in the world for a low rate of unionization, a high ranking on wage flexibility, and a high ranking of cooperation between labor and employers. Guatemala also has a good record for retaining talent and relatively high ranking $\left(46^{\text {th }}\right)$ on pay and productivity (World Economic Forum Global Competitiveness Index 2015).

\subsubsection{Education Level}

The average Guatemalan male finishes 11 years of school, the average female, 10 years. Only $18 \%$ of Guatemalans are enrolled in colleges and universities; still fewer graduate. Again, the percentages are higher in urban than in rural areas. The quality of education is high in some disciplines, including management, but weak in areas of 
engineering and technology (World Economic Forum Global Competitiveness Index, 2015).

In many instances, businesses depend on in-house training programs and on-the-job experience for operating level employees. In Guatemala, it is difficult to find formal training for fork truck drivers, machine operators, and other jobs of this nature. That is in part due to the low level of industrialization and lack of infrastructure (World Economic Forum Global Competitiveness Index, 2015).

\subsubsection{Logistics Competence}

On the Logistics Performance Index (LPI), Guatemala stands midrange among developing countries, ahead of Costa Rica, but behind Mexico and Panama. Its strongest attribute is timeliness, its weakest, infrastructure. On the specific measure of logistics competence, it is the weakest of the five countries in this review, though not far behind Panama and Costa Rica (lpi.worldbank.org, 2016). This means that transportation providers and third parties are competent, but not at the same level as their counterparts in the developed world.

Specific training programs for supply-chain education are limited and those available are only in Guatemala City. Training for supply chain jobs is largely informal via on-thejob experience. This includes operational jobs including lifttruck drivers and warehouse personnel. The original researchers found similar circumstances in developing countries for supply-chain related jobs (Srinavasan et al., 2014). Consequently, statistics related to education, graduation rates, and other proxy measures were used. Student teams followed the same protocol in this replication.

\subsubsection{Customs and Security Competence}

Guatemala's biggest problem in this arena is the business cost of organized crime. According to the World Economic Forum, Guatemala ranks last, or $144^{\text {th }}$ of 144 , on this element of their competitive index with a score of 2.5. The major problem stems from drug cartels, who seem to operate with near impunity, especially in the northern regions of the country, near the Mexican border. For perspective, the US ranks $73^{\text {rd }}$ with a score of 4.7 , while the United Arab Emirates rank $1^{\text {st }}$ with a score of 6.8. In an obviously related measure, Guatemala also ranks 142 of 144 on the business costs of violence and crime with a score of 2.1. The US ranks $85^{\text {th }}$ with a score of 4.2 , Qatar, $1^{\text {st }}$ with 6.5. On the reliability of police, Guatemala ranks $124^{\text {th }}$ with a score of 2.9 , the US $22^{\text {nd }}$ with a 5.7. Finland ranks $1^{\text {st }}$ with a 6.7. Guatemala fares better on the business costs of terrorism, ranking $88^{\text {th }}$ with a score of 4.9 , while the US ranks $118^{\text {th }}$ with a score of 4.2. Finland again ranks $1^{\text {st }}$ with a score of 6.7 (World Economic Forum Global Competitiveness Index, 2015).

In Guatemala, customer procedures rank $88^{\text {th }}$ with a score of 3.7 , while the US ranks 33 with a score of 4.8 . Singapore ranks $1^{\text {st }}$ with a score of 6.1. But Guatemala's ranking must also be put in the context of corruption, especially bribes related to imports and exports. Former President Perez Molina was driven from office in 2015 in a scandal based on taking bribes in exchange for lower tariffs for companies seeking to import goods into Guatemala (Romo, 2015). In still another scandal, Molina and others are accused of taking a 'commission' of $\$ 24.5$ million to allow a
Operations and Supply Chain Management 10(2) pp. 47 - 62 (02017

Spanish company, Grup TCB, to obtain a port contract (FoxNews.com/Latino, 2016). Given this background information on Guatemala, this research asked business professionals to assign a grade to each of the four EPIC variables for the country..

\section{RESEARCH METHODOLOGY}

The methodology used in this research involved a seven-step process as described below. First teams of master's level business students read Srinivasan, et al. (2014)'s EPIC framework as detailed in the book, Global Supply Chains: Evaluating Regions on an EPIC Framework - Economy, Politics, Infrastructure, and Competence. They also participated in several interactive lectures by one of the researchers on the EPIC framework in their MBA Marketing Management Class. Second, the MBA students were introduced in detail to the sources used by Srinivasan et al. (2014) to evaluate the supply chain readiness of 55 countries. Third, the students were given tables that included the region for Guatemala. Fourth, the students were divided into teams of three to six individuals and given the assignment of 'grading' Guatemala using the same processes and data sources used by the original researchers (Srinivasan et al., 2014). Fifth, the students completed their assessments and defended their evaluations of Guatemala in an oral team presentation to the class. Sixth, the researchers complied the results from all the groups along with background information gathered from on-site interviews with Guatemalan NGOs and governmental officials. Finally, results between teams and countries represented by the student raters were compared. The steps in this process are discussed in greater detail in the sections that follow.

\subsection{EPIC Analysis by Teams of Business Professionals}

The methodology included an EPIC analysis of Guatemala by teams of business professionals combined with ethnographic interviews with businesses, NGOs, and governmental officials by three additional researchers, one based in Guatemala for more than two years.

The business professionals were early-to-mid career professional completing an MBA degree. There were two cohorts, one based in Manheim, Germany and the other in Pensacola, Florida. All students were completing a face-toface Marketing Management course as a required MBA course in their respective countries. The rating assignment was a major part of the course requirement to study supply chains in a marketing context. The Manheim-based students included three individuals from Switzerland, one from Ireland, one from Moldova, and the remaining 13 from Germany. The US sample of 22 students were all based in Northern Florida.

Students first read the book Global Supply Chains: Evaluating Regions on an EPIC Framework-Economy, Politics, Infrastructure, and Competence: "EPIC", Structure-Economy, Politics, Infrastructure, and Competence. (Srinivasan, et al., 2014) and completed an incourse essay examination of the materials. Next, students were instructed to replicate the book's methodology while working in teams of three to six individuals. The teams were self-selected. They were told to replicate the process to the extent possible and consulting the same sources for 
Helms et.al : Assessing The Epic Framework: Guatemala

Operations and Supply Chain Management 10(2) pp. 47-62 (C2017

Guatemala (as shown in Table 1). They used the same framework and weightings, as shown in Table 2, to assign letter grades, including plusses and minuses for each of the EPIC framework categories, along with an overall country grade for Guatemala. Students were familiar with the A+ to F- grading scheme as it is also the scheme used to evaluate their own work in their MBA courses. Students were given the entire term to complete the project, but the Florida teams were on a 15 -week schedule while the German teams were on an 8-week Executive-MBA schedule. The eight teams' (four in Germany and four in the US) findings were compiled in a single table with both subcategory and overall country grades. None of the students had ever visited or lived in Guatemala.

Table 2. Weightings of the EPIC Variables

\begin{tabular}{|c|c|c|c|c|c|}
\hline Economy & $\begin{array}{c}\text { Economic Output and } \\
\text { Growth }\end{array}$ & Population Size & FDI & $\begin{array}{l}\text { Exchange Rate } \\
\text { and Stability/ CPI }\end{array}$ & Trade Imbalance \\
\hline $30 \%$ of total EPIC score & $35 \%$ & $25 \%$ & $20 \%$ & $15 \%$ & $5 \%$ \\
\hline Politics & Ease of Doing Business & Legal Framework & Political Stability & \multicolumn{2}{|c|}{ Intellectual Rights } \\
\hline $20 \%$ of total EPIC score & $30 \%$ & $30 \%$ & $25 \%$ & \multicolumn{2}{|c|}{$15 \%$} \\
\hline Infrastructure & Physical Infrastructure & \multicolumn{2}{|c|}{ Energy Infrastructure } & \multicolumn{2}{|c|}{ Connectivity } \\
\hline $30 \%$ of total EPIC score & $50 \%$ & \multicolumn{2}{|c|}{$25 \%$} & \multicolumn{2}{|c|}{$25 \%$} \\
\hline Competence & Labor Relations & Education Levels & $\begin{array}{c}\text { Logistics } \\
\text { Competence }\end{array}$ & \multicolumn{2}{|c|}{ Customs and Security } \\
\hline $20 \%$ of total EPIC score & $25 \%$ & $25 \%$ & $40 \%$ & \multicolumn{2}{|c|}{$10 \%$} \\
\hline
\end{tabular}

Source: Srinivasan, Mandyam; Theodore Stank, Phillipe-Pierre Dornier, and Kenneth Peterson, (2014) Global Supply Chains: Evaluating Regions on an EPIC Framework - Economy, Politics, Infrastructure, and Competence. New York: McGraw Hill.

The students received the tables shown in Appendix 1. These tables were taken directly from the EPIC book, Global Supply Chains: Evaluating Regions on an EPIC Framework-Economy, Politics, Infrastructure, and Competence: "EPIC" Structure-Economy, Politics, Infrastructure, and Competence (Srinivasan, et al., 2014), except in these tables the scores for Canada were removed and Guatemala was added in the country column of the tables and blank spaces were included for each of the sub-variables. Scores for other countries in the region were left untouched from the original content (Srinivasan et al., 2014). This detail is important because of the possibility of an anchoring effect which is discussed later.

Students presented their findings in-class and turned in tables that included both their scores and the justifications for their scores. This is again in keeping with the process followed by Srinivasan et al. (2014).Students also presented tables that justified their grades in each broad category. An example of the justifications is shown in Table 3. Space limitations prevent the inclusion of multiple tables of this nature.

Table 3. Example of German Team Submissions Justifying Assigned Grades: Strengths and Weaknesses Summary

\begin{tabular}{|c|c|c|}
\hline Grade & Strengths & Weaknesses \\
\hline USA: B+ & $\begin{array}{l}\text { Absolute volume of GDP; global percent of GDP; absolute } \\
\text { amount of exports; consumer price inflation low; stable } \\
\text { exchange rates; large FDI; diversification of economic sectors; } \\
\text { population and workforce growth (mainly due to immigration } \\
\text { from Mexico). }\end{array}$ & $\begin{array}{l}\text { High costs of taxes, land, labor, and capital; } \\
\text { GDP growth low; negative balance of trade; } \\
\text { negative budget surplus could cause instability; } \\
\text { again population. }\end{array}$ \\
\hline Guatemala: B & 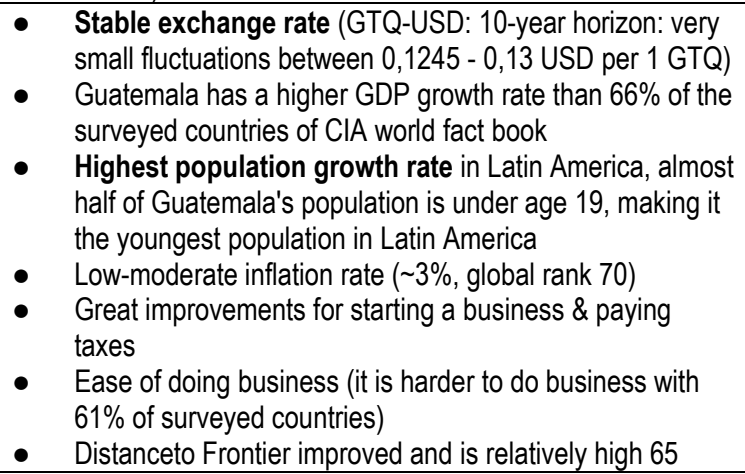 & $\begin{array}{l}\text { GDP per capita } \$ 7500 \text { / year, which is } \\
\text { roughly one-half that of the average for } \\
\text { Latin America and the Caribbean } \\
\text { - } \quad \text { More than half of the population is below } \\
\text { the national poverty line } \\
\text { - } 13 \% \text { of the population lives in extreme } \\
\text { poverty, distribution of income highly } \\
\text { unequal, } \\
\text { - } \quad \text { Imly } 82 \% \text { can read \& write, } \\
\text { - } \quad \text { High fluctuation in } \mathrm{FDI} \text { - up to } 400 \%\end{array}$ \\
\hline Mexico: B+ & $\begin{array}{l}\text { Real GDP growth; export volume; proximity, economic, and } \\
\text { regulatory ties to the United States; low cost of living; low unit } \\
\text { labor costs; low cost of capital; raw commodity energy } \\
\text { reserves; relatively stable business environment and } \\
\text { regulations for FDI. }\end{array}$ & $\begin{array}{l}\text { High consumer price inflation; unstable } \\
\text { exchange rate; low and risky capital markets; } \\
\text { low FDI; high poverty and poor distribution of } \\
\text { wealth; poor tax collection rates; strong "black } \\
\text { market" economy; regional variation if high, with } \\
\text { the south poor, underdeveloped, and educated, } \\
\text { poor education system. }\end{array}$ \\
\hline Costa Rica: C+ & $\begin{array}{l}\text { Trade ties within and beyond the Western Hemisphere; } \\
\text { economic activity to expand long term; recent history of location } \\
\text { of large electronic firms. }\end{array}$ & $\begin{array}{l}\text { Economic growth tied to the United States; } \\
\text { fiscal account deficit to continue based on } \\
\text { needed expenditures on security and } \\
\text { infrastructure. }\end{array}$ \\
\hline
\end{tabular}


Table 3. Example of German Team Submissions Justifying Assigned Grades: Strengths and Weaknesses Summary

\begin{tabular}{|l|l|l|}
\hline \multicolumn{1}{|c|}{ Grade } & \multicolumn{1}{|c|}{ Strengths } & \multicolumn{1}{c|}{ Weaknesses } \\
\hline Panama: B & $\begin{array}{l}\text { One of the world's fastest growing economics; dollarized } \\
\text { economy that removed exchange rate risk; Panama Canal and } \\
\text { Colón free trade zone; privatization of the power generation } \\
\text { system and telecoms, and the relative flexibility of the labor } \\
\text { market; FTA with USA and other Central American nations, } \\
\text { awaiting passage with Canada; commitment to fiscal prudency. }\end{array}$ & $\begin{array}{l}\text { Poor income distribution; economy linked to } \\
\text { health of USA and EU based on volume of } \\
\text { freight traversing Panama Canal; fiscal debt. }\end{array}$ \\
\end{tabular}

\subsection{Formal Interviews with Businesses, NGOs, and Governmental Officials}

To supplement the analysis by the business professionals, one of the Guatemalan-based researchers conducted more than fifty interviews with business professional, governmental officials and leaders of nongovernmental organizations (NGOs) located in Guatemala, and primarily in the cities of Antigua, Guatemala City, and Quetzaltenango. The interviews were unstructured yet oriented around the EPIC framework variables. The Guatemalan researcher, fluent in Spanish, also worked with local interpreters and translators to ensure the quality of the interpretation of the interviews. The purpose of the interviews was to support the quantitative analysis and add a qualitative context to the findings. The results of these processes are discussed below.

\section{RESULTS}

The eight teams assigned overall grades that ranged from $\mathrm{C}$ to B- as shown in Table 4. The German teams assigned overall grades one-half grade higher than the US teams. The US teams assigned three C's and a $\mathrm{C}+$ while the German teams assigned three C+'s and a B-. Not surprisingly, the grades for each of the four EPIC subcategories (Economy, Politics, Infrastructure, and Competence) were also similarly closely clustered.

Table 4. EPIC Analysis by MBA Teams: Germany And The United States (Economy Dimension Grades)

\begin{tabular}{|c|c|c|c|c|c|c|}
\hline & $\begin{array}{l}\text { Economic Output } \\
\text { and Growth }\end{array}$ & Population & $\begin{array}{l}\text { Foreign Direct } \\
\text { Investment }\end{array}$ & $\begin{array}{l}\text { Exchange Rate } \\
\text { Stability/CPI }\end{array}$ & Balance of Trade & Overall Economy \\
\hline German 1 & B & B & B- & A & C & B \\
\hline German 2 & B- or C+ & B & C+ & B & C+ & B- \\
\hline German 3 & C+ & B & C & B & B- & B- \\
\hline German 4 & B-/C+ & B & C+ & B & C+ & B \\
\hline US 1 & B- & B & C & B- & B & B- \\
\hline US 2 & B- & B & C+ & B+ & C- & B \\
\hline US 3 & B- & B- & C- & C- & C+ & C \\
\hline UX4 & B & C+ & C & B+ & C & B- \\
\hline
\end{tabular}

Table 5. EPIC Analysis by MBA Teams: Germany And The United States (Politics Dimension Grades)

\begin{tabular}{|l|c|c|c|c|c|}
\hline & $\begin{array}{c}\text { Ease of Doing } \\
\text { Business }\end{array}$ & Legal Framework & Political Stability & Intellectual Property Rights & Overall Politics \\
\hline German 1 & C & C & B- & D+ & C+ \\
\hline German 2 & C- & D+ & B & B- & C- \\
\hline German 3 & B- & D & C- & D & C- \\
\hline German 4 & C+ & D & B- & C & C \\
\hline US 1 & C & D+ & F & D+ & D+ \\
\hline US 2 & C- & D+ & C & C & C- \\
\hline US 3 & C- & D+ & C- & D- & D- \\
\hline US 4 & D & D- & F+ & & \\
\hline
\end{tabular}

Table 6. EPIC Analysis by MBA Teams: Germany And The United States (Infrastructure Dimension Grades)

\begin{tabular}{|l|c|c|c|c|}
\hline & $\begin{array}{c}\text { Transportation } \\
\text { Infrastructure }\end{array}$ & Energy Infrastructure & Connectivity & Overall Infrastructure \\
\hline German 1 & C- & B- & B+ & C+ \\
\hline German 2 & C- & B & C & C+ \\
\hline German 3 & C & B- & B+ & C+ \\
\hline German 4 & C & B- & B- & C+ \\
\hline US 1 & D+ & B- & C+ & C \\
\hline US 2 & D+ & C & B- & C \\
\hline US 3 & B- & B+ & C- & B- \\
\hline US 4 & C- & C & C- \\
\hline
\end{tabular}


Table 7. EPIC Analysis by MBA Teams: Germany And The United States (Competence Dimension Grades)

\begin{tabular}{|c|c|c|c|c|c|}
\hline- & $\begin{array}{c}\text { Labor } \\
\text { Relations }\end{array}$ & $\begin{array}{c}\text { Education } \\
\text { Levels }\end{array}$ & $\begin{array}{c}\text { Logistics } \\
\text { Competence }\end{array}$ & $\begin{array}{l}\text { Customs and } \\
\text { Security }\end{array}$ & Overall Competence \\
\hline German 1 & $\mathrm{~B}+$ & $\mathrm{C}+$ & $\mathrm{C}$ & B- & $\mathrm{C}+$ \\
\hline German 2 & B- & $\mathrm{C}-$ & $\mathrm{C}+$ & $\mathrm{C}+$ & $\mathrm{C}+$ \\
\hline German 3 & $\mathrm{~B}+$ & $\mathrm{C}+$ & $\mathrm{C}$ & B- & $\mathrm{C}+$ \\
\hline German 4 & $\mathrm{~B}-/ \mathrm{C}+$ & $\mathrm{C}-$ & $\mathrm{C}+$ & $\mathrm{C}+$ & $\mathrm{C}+$ \\
\hline US 1 & $\mathrm{~B}+$ & $\mathrm{C}+$ & $\mathrm{C}+$ & B- & B- \\
\hline US 2 & $\mathrm{C}-$ & $\mathrm{C}+$ & B- & $\mathrm{C}-$ & $\mathrm{C}+$ \\
\hline US 3 & $\mathrm{~B}+$ & $\mathrm{C}+$ & $\mathrm{C}$ & $\mathrm{C}-$ & $\mathrm{C}$ \\
\hline US 4 & $\mathrm{~B}+$ & $\mathrm{C}+$ & $\mathrm{C}$ & B- & $\mathrm{C}+$ \\
\hline
\end{tabular}

For example, Economy scores ranged from $\mathrm{C}$ to $\mathrm{B}$ - for all the teams, but in this case, the US teams assigned a $\mathrm{C}$ while all other teams assigned grades of B or B-. Politics received the lowest scores with a range of $\mathrm{D}-$ to $\mathrm{C}+$. Again US teams assigned lower scores than their German-based counterparts. Three US teams assigned D- or D+ to Politics while all the German teams' grades ranged between $\mathrm{C}$ - and $\mathrm{B}+$. On Infrastructure, the teams were again consistent with a grade range of $\mathrm{C}$ - to $\mathrm{B}-$, but in this case there was only one $\mathrm{B}-$ and the remainder of the grades ranged from $\mathrm{C}$ - to $\mathrm{C}+$. Finally, on the Competence sub-score, the grades ranged again from $\mathrm{C}$ to B-, but this time, six of the eight grades were $\mathrm{C}+$. The pattern of differences in grades between the German and US-based teams remained consistent.

The overall grade on the Economy dimension ranged from C to B, with four B-'s, three B's and a C. The Economic Output and Growth were very consistent grades ranging from $\mathrm{B}-/ \mathrm{C}+$ to B. Two of the Germany teams could not determine between $\mathrm{B}-$ and $\mathrm{C}+$. Population scores ranged from $\mathrm{C}+$ to $\mathrm{B}$, with six B's assigned. Foreign and Direct Investment grades ranged from $\mathrm{C}$ - to $\mathrm{B}-$ with three $\mathrm{C}+\mathrm{s}$, three $\mathrm{C}$ 's, one B-, and one C-. The score for Exchange Rate Stability and the Consumer Price Index ranged from $\mathrm{C}$ - to A with three Bs, two $\mathrm{B}+\mathrm{s}$, an $\mathrm{A}$, and $\mathrm{B}-$, and a $\mathrm{C}-$. We found this variation in scores somewhat surprising given the long term stability of the Guatemalan quetzal currency against the US dollar. On Balance of Trade, grades ranged from $\mathrm{C}$ - to $\mathrm{B}$ with three $\mathrm{C}+\mathrm{s}$, two Cs, and a C-, a B- and a B.

Of the four EPIC dimensions, grades for Politics were the lowest. Overall the Politics grades ranged from a D- to a $\mathrm{C}+$ with US teams consistently assigning lower scores. The US teams had two D+'s, a C- and a D-. The German teams had a $\mathrm{C}+$, two $\mathrm{C}$-s and a C. On Ease of Doing Business the grades ranged from $\mathrm{D}$ to $\mathrm{B}$ - with three $\mathrm{C}-\mathrm{s}$, two C's a $\mathrm{C}+$ and a B- and a D. On Legal Framework, the grades ranged from D- to C with four D+'s, two D's a C and a D-. On Political Stability the grades varied widely. They ranged from $\mathrm{F}$ to $\mathrm{B}-$ with two B-s, two C-s, a C a B an F and an F+. The differences between the US teams and the German teams were most apparent on Political Stability. The US teams assigned the $\mathrm{F}$ grades and the $\mathrm{F}+$ while the German teams assigned the B and the two B-s. The Political Stability grades may have been influenced by the fact that immigration from
Guatemala to the US was controversial at the time of the assignment (Orlinsky\& Gordon, 2015). On Intellectual Property Rights scores ranged from D- to B-. Again scores from US teams were generally lower than for their German counterparts. In this instance one German team assigned a grade of B- that was an anomaly. There were two D's, two D+'s, a D-, a C-, a C, and a B-.

The overall grades for Infrastructure ranged from $\mathrm{C}$ - to B-. All four German teams' assigned grades of C+. The US teams assigned two Cs a C- and a B-. On Transportation Infrastructure the grades ranged from C- to B-. The US teams again assigned lower grades than the German teams. The German teams assigned two $\mathrm{Cs}$ and two $\mathrm{C}$ - grades, while the US team assigned two D+, a C- and a B-. On Energy Infrastructure the grades ranged from $\mathrm{C}$ to $\mathrm{B}+$. Three of the German teams assigned B-, one assigned a B. Two US teams assigned $\mathrm{C}$ while one assigned a $\mathrm{B}-$ and the other a $\mathrm{B}+$. On Connectivity the grades ranged from $\mathrm{C}-$ to $\mathrm{B}+$. Three of the German teams assigned the $\mathrm{B}+\mathrm{s}$, while one assigned a $\mathrm{C}$. Two US teams assigned B-s and one assigned a $\mathrm{C}$ - and the other a $\mathrm{C}+$.

The overall grades for the Logistics Competence EPIC dimension ranged from $\mathrm{C}$ to $\mathrm{B}-$. Six of the scores including all four of the German teams were $\mathrm{C}+$. One US team assigned a $\mathrm{B}$ - and one a $\mathrm{C}$. On Labor Relations the scores ranged from $\mathrm{C}$ - to $\mathrm{B}+$. There were five $\mathrm{B}+\mathrm{s}$, a $\mathrm{B}-/ \mathrm{C}+\mathrm{a}$ and a $\mathrm{C}$-. For Education Levels, the grades ranged from $\mathrm{C}$ to $\mathrm{C}+$. All four US teams assigned grades of $\mathrm{C}+$, while two German teams assigned $\mathrm{C}+$ and the other two assigned $\mathrm{C}$ grades. On Logistics Competence, the scores ranged from $\mathrm{C}$ to B-. Four teams assigned C's, three teams' assigned $\mathrm{C}+\mathrm{s}$, and one assigned a B-. On Customs and Security grades ranged from $\mathrm{C}$ - to $\mathrm{B}-$ with four $\mathrm{B}-\mathrm{s}$, two $\mathrm{C}+\mathrm{s}$ and two $\mathrm{C}-\mathrm{s}$.

It is worthy to note that one US team was especially negative on the Politics dimension. This team assigned two $\mathrm{D}-\mathrm{s}$, a D, and an F+ to the four dimensions that comprised Politics in the EPIC framework. In their discussion of these grades, the one US team was especially concerned with the impact of the drug cartels and illegal drug trade in Guatemala.All teams submitted detailed tables to support their assigned EPIC grades. Examples in each category are shown in Table 4.

Table 8. EPIC Analysis by MBA Teams: Germany And The United States Overall Grade Summary

\begin{tabular}{|l|c|c|c|c|c|}
\hline & Economy & Politics & Infrastructure & Competence & $\begin{array}{c}\text { Overall Supply Chain } \\
\text { Readiness }\end{array}$ \\
\hline German 1 & B & C + & C + & C + & B- \\
\hline German 2 & B- & C- & C & C + & C + \\
\hline German 3 & B- & C- & C $~$ & C + & C + \\
\hline German 4 & B- & C & C + & C + & C + \\
\hline US 1 & B- & D + & C & B- & \\
\hline
\end{tabular}


Table 8. EPIC Analysis by MBA Teams: Germany And The United States Overall Grade Summary

\begin{tabular}{|l|c|c|c|c|c|}
\hline & Economy & Politics & Infrastructure & Competence & $\begin{array}{c}\text { Overall Supply Chain } \\
\text { Readiness }\end{array}$ \\
\hline US 2 & B & D + & C & C+ & C \\
\hline US 3 & C & C- & B- & C & C \\
\hline US 4 & B- & D- & C- & C+ & C \\
\hline
\end{tabular}

\section{DISCUSSION AND AREAS FOR FUTURE RESEARCH}

This research has answered the two research questions introduced earlier. First in considering how readily the EPIC framework can be applied by business professionals who are not necessarily experts in supply chain management, it appears that the EPIC framework can be readily applied by business professionals and while it is time consuming in a team environment, it produces results that should be useful in making broad, strategic supply-chain decisions about locating operations in specific countries. In this regard it is similar to other structured approaches like checklists and other grid-based analyses. The EPIC framework add discipline to data gathering and informs judgment. The fact that it helps to combine both quantitative and qualitative material is a further advantage to using the EPIC framework. The EPIC framework is designed to examine elements of the business climate affecting supply chains, providing a complex context to specific measures including the Logistics Performance Index.

However, the process has some limitations. It was apparent that US-based teams had a slightly lower opinion of the supply chain readiness of Guatemala than did their German counterparts. This could be due in part to the media coverage received about Guatemala during the time of the research. The German students were not exposed to the same media coverage of Guatemala as the US students. This suggests that some attention should be paid to the availability effect and to the anchoring effect that might affect the grading process. Both anchoring effect and availability effect suggest directions for future research in the application of the EPIC Framework.

Because this research was not aimed at producing a single, comprehensive rating for the country of Guatemala, the authors did not address rater differences. However, in practical circumstances this might be essential. In that case, we would recommend discarding extreme ratings at the subcategory level, for example in "Labor Relations" under "Competence", before arriving at an average rating. In practice, the number of raters would be fewer than used in this research study.

For example, the students in this research were given blank tables showing the US and nearby countries. If teams were given completed tables with lower scores indicated for less developed countries (i.e., Africa), it could influence them to assign lower scores to the countries they were analyzing. In addition, it may be that short-term experimental designs can show the influence of availability of specific kinds of information or the effect of timing on score assignment.

Research question two is answered in part by the above discussion of question one. It is clear the EPIC Framework can be readily applied, however, it must be applied consistently. Does the methodology transfer across backgrounds? The results in this research show some consistent pattern for the overall grades but somewhat less consistency in some of the detailed subcategories within the EPIC analysis. This suggests that for more consistent results, usage of the EPIC framework should carefully consider the media context in which scores are being developed. In addition, following the process in an iterative fashion and using another team not involved in the first analytical process to break the ties in scores or to assign different weightings to EPIC could be useful. While this study used the weightings shown in the original research (Srivinasan, et al., 2014), an organization might assign different weightings to individual criteria. Before we can draw a final conclusion on the answer to research questions as to whether teams produce consistent results when they apply the EPIC framework to the same country, replications of this research are needed both with and without modifications. It would also be useful to see how other teams evaluated some of the same countries from the original EPIC classification (Srivinasan, et al., 2014).

Clearly this EPIC framework depends on data that are made available by a wide range of organizations including the CIA, the World Bank and the World Economic Forum. The results, consequently, will depend on the accuracy and timeliness of data gathered by these organizations. As discussed under data on Guatemala, official employment differs greatly from the way unemployment is calculated and measured in other countries. For example, the unemployment rate in the US is not based on the idea of having worked only one hour in a prior week, however, some of the variations in the data that are available and the problems that those variations cause are overcome by the amount of data gathered by the developing framework.

Further studies should have researchers grade the same 55 locations as in the original EPIC study (Srivinasan, et al., 2014) and see how well it replicates and if there is bias toward an individual's own country or region. Individuals in this study benchmarked Guatemala with the Central and North American Region from the original EPIC study not including Canada. Further research should determine if the rankings (of anchor, peer countries) make a difference. For example, if Guatemala were ranked on forms that included data from less developed African countries, for example, would the framing/anchoring make a difference? Research on how managers using similar information make decisions is also needed to compare to the variables and weightings within the EPIC Framework for validation. It could be subjected to further assessment as a pedagogical tool. The framework does push students to understand a variety of factors that influence supply chain location decisions and supply chain performance. As a teaching pedagogy, it is useful to assess student satisfaction with applying this framework and compare its use to learning of supply chain concepts within a global context using other teaching methods. 


\section{REFERENCES}

Allen, J. (n.d.) Train Travel in Guatemala. USAToday, accessed June 11, 2016 at http://traveltips.usatoday.com/train-travelguatemala-36077.html

Bettis, R. A., Helfat, C. E., \& Shaver, J. M. (2016). The necessity, logic, and forms of replication. Strategic Management Journal. Strategic Management Journal (forthcoming). Accessed online via EarlyCite.

Boylan, J. E., Goodwin, P., Mohammadipour, M., \&Syntetos, A. A. (2015). Reproducibility in forecasting research. International Journal of Forecasting 31(1), pp. 79-90.

CIA World FactBook (2015) Accessed September 17, 2016 at: (https:/www.cia.gov/library/ publications/the-worldfactbook/geos/gt.html)

Competitiveness Rankings, World Economic Forum, Accessed August 1, 2016 at

$\mathrm{http} / / /$ reports.weforum.org/global-competitiveness-report-20142015/rankings/

Crick, T., Hall, B. A., \&Ishtiaq, S. (2014). Can I Implement Your Algorithm?: A Model for Reproducible Research Software. arXiv preprint arXiv:1407.5981.

Ease of Doing Business Index, The World Bank. Accessed August 1, $2016 \quad$ at: http://data.worldbank.org/indicator/IC.BUS.EASE.XQ.

Ellram, L. M., Tate, W. L., \&Feitzinger, E. G. (2013). FactorMarket Rivalry and Competition for Supply Chain Resources. Journal of Supply Chain Management49(1), pp. 29-46.

Ellram, L. M., Tate, W. L., \& Petersen, K. J. (2013). Offshoring and reshoring: an update on the manufacturing location decision. Journal of Supply Chain Management49(2), pp. 14-22.

Electrifying Guatemala: Clean Energy and Development. Accessed September 26, 2016 at: https://nacla.org/news/electrifying-guatemala-clean-energyand-development

Feigenbaum, S. and Levy, D. M. (1993b). The market for (ir) reproducible econometrics. Social Epistemology, 7(3):215232.

Fox News Latino (2016). Guatemalan former president accused of taking bribes from Spanish company. April, 16, 2016. Accessed on June 27, 2016 at http://atino.foxnews.com/latino/news/2016/04/16/guatemal an-former-president-accused-taking-bribes-from-spanishcompany/

Gagné, G. (2011). Free trade and cultural policies: Evidence from three US agreements. Journal of World Trade 45(6), pp. 1267-1284. Retrieved from http://ezproxy.lib.uwf.edu/ login?url=http:// search.proquest.com/docview/915267563?accountid=14787

Gagné, G. (2011). Free trade and cultural policies: Evidence from three US agreements. Journal of World Trade 45(6), pp. 1267-1284. Retrieved from http://ezproxy.lib.uwf.edu/login? url=http://search.proquest.com/docview/915267563?account id $=14787$

Greenbaum, D. (2009). Determining optimal levels of intellectual property protection in developing nations: is less really more? is more really less? Current Science 97(1), p. 1.

Guatemala defies 'Monsanto Law' Pushed by US as Part of Trade Agreement, (2014). The Russian Times. September 3, available at: http://on.rt.com/uqj4ly

Guatemala's Indigenous Community Threatened by Mega-Dam Project, (2014), The Guardian.com. Accessed September 17, 2016 at http://www.theguardian.com/globaldevelopment/2014/may/21/guatemala-indigenouscommunity-mega-dam-project

Guatemala - Infrastructure, Power, and Communications. (n.d.). Accessed September 17, 2016 at: http://www.nationsencyclopedia.com/economies/Americas/
Guatemala-INFRASTRUCTURE-POWER-AND-

COMMUNICATIONS.html

Guatemala - Telecoms, Mobile, Broadband and Digital Media Statistics and Analyses, (n.d.) Accessed September 17, 2016 at: https://www.budde.com.au/Research/GuatemalaTelecoms-Mobile-Broadband-and-Digital-Media-Statisticsand-Analyses

Harrison, N. (2005). CAFTA fears. Appropriate Technology 32(2), pp. 43-44. Retrieved http://ezproxy.lib.uwf.edu/login?url=http://search.proquest.c om/docview/200038398?accountid $=14787$

LeMay, S.A., Dwyer, M. J., and Helms, M. M. (2016). World Views and the Evaluation of NGO Supply Chains: Thirteen Cases from Guatemala. Operations and Supply Chain Management 90(2). Pp. 90-104.

Hoekman, B. (2015). Trade and growth-end of an era?.The Global Trade Slowdown: A New Normal?, p. 3.

Hutcheson, K. A. (2014). Sub-Saharan Africa: The New China? University of Tennessee Honors Thesis Project, University of Tennessee Honors Program, TRACE: Tennessee Research and Creative Exchange. Available at: http://trace.tennessee.edu/utk_chanhonoproj/1725

Ioannidis, J. P. (2015, November). Failure to Replicate: Sound the Alarm. In Cerebrum: the Dana Forum on Brain Science (Vol. 2015). Dana Foundation.

Jacobson, R. S. (2013). The opportunities ahead: Policy in the western hemisphere. The Brown Journal of World Affairs 19(2), pp. 19-26. Retrieved from http://ezproxy.lib.uwf.edu/login?url=http://search.proquest.c om/docview/1649691839? accountid $=14787$

Krause, A. (2016). Reproducible Research in Real Estate: A Review and an Example. Journal of Real Estate Practice and Education 19(1), pp. 69-85.

Lewis, M. K. (2011). The prisoners' dilemma posed by free trade agreements: Can open access provisions provide an escape? Chicago Journal of International Law 11(2), pp. 631-661. Retrieved

from http://ezproxy.lib.uwf.edu/login?url=http://search.proquest.c om/ docview/855632020? accountid $=14787$

Logistics Performance Index (LPI), The World Bank, Accessed August 2, 2016 at http://lpi.worldbank.org/

McCullough, B. D. (2009). Open access economics journals and the market for reproducible economic research. Economic Analysis and Policy 39(1), pp. 117-126.

Orlinsky, K. and Gordon, I. (2015). Children Do Not Migrate They Flee: Striking Photos from Poverty-Ravaged Guatemala Mother Jones at: http://www.motherjones.com/ media/2015/02/child-migrants-Guatemala-photos-KatieOrlinsky

Overview: The TRIPS Agreement, World Trade Organization. Accessed August $\quad 1, \quad 2016$ at:https://www.wto.org/english/tratop_e/trips_e/intel2_e.ht $\mathrm{m}$

Peng, R. D. (2011). Reproducible research in computational science. Science, 334(6060), p. 1226.

Political Instability Index 2009-2010. Accessed August 1, 2016 at: http://wikirating.org

/wiki/Data_(countries)/List_of_countries_by_Political_Insta bility_Index_2009-2010

Quarles, B. J. (2011). John Rawls' difference principle: evidence from Guatemala. Review of Business \& Finance Case Studies 2(1), pp. 69-78.

Reeves, B. (2014). Guatemala: Backlash Continues over hydroelectric power projects in Guatemala. The Tico Times News. Available on-line at:http://www.ticotimes.net/2014 /03/10/social-discontent-swells-over-hydroelectric-powerprojects-in-guatemala

Srinivasan, Mandyam; Theodore Stank, Phillipe-Pierre Dornier, and Kenneth Peterson, (2014),Global Supply Chains: Evaluating Regions on an EPIC Framework - Economy, 
Politics, Infrastructure, and Competence, McGraw Hill, New York.

Stank, T., Burnette, M. and Dittman, P. (2014). Global Supply Chains. (available at http://globalsupplychaininstitute.utk.edu/publications/docu ments/GSCI-EPIC-paper.pdf).

Romo, Rafael. (2015). Guatemala's top court approves bid to impeach President amid scandal, August 26, 2015. Available at http://www.cnn.com/2015/ 08/26/ americas/guatemalapresident-scandal/

Tai-Yue, W., Hsin-Ying, L., Zamora, E. A., Talisayon, S. D., Supangco, V. T., Gutierrez, B. P. B., \&Patalinghug, E. E. (2004). A research framework for evaluating the competitiveness of developing countries: An example of the phi. Asia Pacific Management Review 9(2). Retrieved from http://ezproxy.lib.uwf.edu/login?url=

http://search.proquest.com/docview/1115703979?accountid $=14787$

Tesfom, G., \& Lutz, C. (2008). Evaluating the effectiveness of export support services in developing countries. International Journal of Emerging Market, 3(4), pp. 364-377. doi:http://dx.doi.org/10.1108/17468800810906075

Tsang, E. W. K. and Kwan, K. (1999). Replications and Theory Development in Organizational Science: A Critical Realist Perspective.Academy of Management Review 24, pp. 795780.

US Department of State (2015). Accessed September 17, 2016 at http://www.state.gov/g/drl/rls/
Vadi, V. S. (2008). Cultural heritage and international investment law: A stormy relationship. International Journal of Cultural Property, 15(1), pp. 1-24. Retrieved from $\mathrm{http} / /$ ezproxy.lib.uwf.edu/login?url=http://search.proquest.c om/docview/232088269? accountid=14787

Vatamanescu, E., \&Alexandru, V. (2014). Economic and risk analyses for SMEs internationalization projects. A preliminary insight on the rationale of business consulting firms. Management Dynamics in the Knowledge Economy, 2(1), pp. 57-70. Retrieved from $\mathrm{http} / /$ ezproxy.lib.uwf.edu/login?url=http://search.proquest.c om/docview/ 1536151376? accountid=14787

World Bank (2003). Accessed September 17, 2016 at: http://documents.worldbank.org/ curated/en/834751468774873404/pdf/25429.pdf

World Bank (2015). Accessed September 17, 2016 at: http://data.worldbank.org/ indicator/IC.BUS.EASE.XQ

World Economic Forum Global Competitiveness Index 2015. Accessed August 1, 2016 at https://www.weforum.org/reports/global-competitivenessreport-2014-2015.

World Trade Organization (2015). Accessed September 17, 2016 at https://www.wto.org/ english/tratop_e/trips_e/intel2_e.htm.

$\mathrm{Xu}, \mathrm{X}$. (2016). Teaching the Mechanism of Horizontal and Vertical Supply Chain Coordination. Operations and Supply Chain Management 9(2), pp. 131-147.

Xu, L., Zhang, Q., \& Zhang, X. (2011). Evaluating agricultural catastrophic risk. China Agricultural Economic Review 3(4), pp. 451-461.

Dr. Stephen A. LeMay is Associate Professor of Marketing and Logistics at the University of West Florida, and Professor Emeritus of Marketing and Logistics at Mississippi State University. He holds a doctorate in transportation and logistics from the University of Tennessee, Knoxville, an MBA in operations management from the University of Tennessee, Knoxville, and a bachelor's degree in journalism from Northwestern University. He was lead researcher and author on the 1999 book, The Growth and Development of Logistics Personnel, the product of a research project sponsored by the Council of Supply Chain Management Professionals. He also coauthored a textbook, Logistics, that has been translated into Mandarin and Croatian. He led a team that created an assembled the Logistics Toolbox, a collection of educational materials designed for people who are new to logistics work. This work was first published by the CSCMP in 2002, then revised in 2005. Dr. LeMay's published work includes more than 75 academic journal articles and proceedings. His research interests include logistics system design, security, logistics information systems, and logistics human resources issues. He has taught a wide range of business courses including logistics, marketing, operations management, and management classes.

Dr. Marilyn M. Helms holds the Sesquicentennial Chair and is a Professor of Management at Dalton State College in Dalton, GA. Dr. Helms holds a Doctorate of Business Administration Degree (as well as an M.B.A. and B.B.A.) from the University of Memphis (TN). Dr. Helms also teaches graduate supply chain/operations management in the Kennesaw Coles College of Business MBA Program on the DSC campus. She is a Certified Fellow in Production and Inventory Management (CFPIM), a Certified Integrated Resources Manager (CIRM), and a Certified Supply Chain Professional (CSCP) of the American Production and Inventory Control Society (APICS). Dr. Helms is also a faculty member of the APICS Basics of Supply Chain Certification Exam committee and works with practitioners and consultants to author and oversee the exam content, study materials, and process. Dr. Helms is a Certified Quality Manager/ Organizational Excellence (CQM/OE) as awarded by the American Society for Quality (ASQ). Her research interests include disaster management, supply chains, strategic management, and entrepreneurship.

Michael J. P. Dwyer is an independent researcher studying humanitarian/disaster relief supply chains and the relationships formed among aid organizations in Antigua, Guatemala. Mr. Dwyer earned his M.B.A. from University of West Florida in 2013. He also holds a B.A. from James Madison University in philosophy. His published works include conference proceedings, "The Antecedents and Consequents of Internal Customer Orientation in the Logistics Workforce" and "The Effects of a Disaster's Onset on Humanitarian Aid Supply Chains," and the journal article "MetaSpace Designs LLC: Can a Lapel-ephant Stay Relevant?" He served as a crew chief in the United States Air Force and as a business development analyst for Catalyst CRE in Pensacola, Florida. His research has appeared in major international conferences and case-related journals. His research interests include the effects of foreign aid workers on domestic populations, long-term community development strategic planning, and networking of non-government organizations deployed in distressed areas. 


\section{APPENDIX}

Table 9. Scores for the Economy Dimension (30\% EPIC Weight)

\begin{tabular}{|l|l|l|l|l|l|l|}
\hline & $\begin{array}{l}\text { Economic } \\
\text { Output and } \\
\text { Growth Rate }\end{array}$ & Population Size & $\begin{array}{l}\text { Foreign Direct } \\
\text { Investment }\end{array}$ & $\begin{array}{l}\text { Exchange Rate } \\
\text { Stability/CPI }\end{array}$ & $\begin{array}{l}\text { Balance of } \\
\text { Trade }\end{array}$ & Overall Grade \\
\hline & $35 \%$ & $25 \%$ & $20 \%$ & $15 \%$ & $5 \%$ & $100 \%$ \\
\hline USA & B- & A & B + & A & B & B + \\
\hline Guatemala & & & & & & \\
\hline Mexico & B & A & B & B & B + & B + \\
\hline Costa Rica & B- & C & B- & B & D & C + \\
\hline Panama & B + & C & B & A- + & B \\
\hline
\end{tabular}

Source: Srinivasan, Mandyam; Theodore Stank, Phillipe-Pierre Dornier, and Kenneth Peterson, (2014) Global Supply Chains: Evaluating Regions on an EPIC Framework - Economy, Politics, Infrastructure, and Competence. New York: McGraw Hill.

Table 10. Strengths and Weaknesses Summary: Economy Dimension

\begin{tabular}{|c|c|c|}
\hline Grade & Strengths & Weaknesses \\
\hline USA: B+ & $\begin{array}{l}\text { Absolute volume of GDP; global percent of GDP; absolute } \\
\text { amount of exports; consumer price inflation low; stable } \\
\text { exchange rates; large FDI; diversification of economic } \\
\text { sectors; population and workforce growth (mainly due to } \\
\text { immigration from Mexico). }\end{array}$ & $\begin{array}{l}\text { High costs of taxes, land, labor, and capital; GDP } \\
\text { growth low; negative balance of trade; negative } \\
\text { budget surplus could cause instability; again } \\
\text { population. }\end{array}$ \\
\hline \multicolumn{3}{|l|}{ Guatemala: } \\
\hline Mexico: $\mathrm{B}+$ & $\begin{array}{l}\text { Real GDP growth; export volume; proximity, economic, and } \\
\text { regulatory ties to the United States; low cost of living; low } \\
\text { unit labor costs; low cost of capital; raw commodity energy } \\
\text { reserves; relatively stable business environment and } \\
\text { regulations for FDI. }\end{array}$ & $\begin{array}{l}\text { High consumer price inflation; unstable exchange } \\
\text { rate; low and risky capital markets; low FDI; high } \\
\text { poverty and poor distribution of wealth; poor tax } \\
\text { collection rates; strong "black market" economy; } \\
\text { regional variation if high, with the south poor, } \\
\text { underdeveloped, and educated, poor education } \\
\text { system. }\end{array}$ \\
\hline Costa Rica: C+ & $\begin{array}{l}\text { Trade ties within and beyond the Western Hemisphere; } \\
\text { economic activity to expand long term; recent history of } \\
\text { location of large electronic firms. }\end{array}$ & $\begin{array}{l}\text { Economic growth tied to the United States; fiscal } \\
\text { account deficit to continue based on needed } \\
\text { expenditures on security and infrastructure. }\end{array}$ \\
\hline Panama: B & $\begin{array}{l}\text { One of the world's fastest growing economics; dollarized } \\
\text { economy that removed exchange rate risk; Panama Canal } \\
\text { and Colón free trade zone; privatization of the power } \\
\text { generation system and telecoms, and the relative flexibility } \\
\text { of the labor market; FTA with USA and other Central } \\
\text { American nations, awaiting passage with Canada; } \\
\text { commitment to fiscal prudency. }\end{array}$ & $\begin{array}{l}\text { Poor income distribution; economy linked to health } \\
\text { of USA and EU based on volume of freight } \\
\text { traversing Panama Canal; fiscal debt. }\end{array}$ \\
\hline
\end{tabular}

Source: Srinivasan, Mandyam; Theodore Stank, Phillipe-Pierre Dornier, and Kenneth Peterson, (2014) Global Supply Chains: Evaluating Regions on an EPIC Framework - Economy, Politics, Infrastructure, and Competence. New York: McGraw Hill.

Table 11. Scores for the Politics Dimension (20\% EPIC Weight)

\begin{tabular}{|l|l|l|l|l|l|}
\hline & $\begin{array}{l}\text { Ease of Doing } \\
\text { Business }\end{array}$ & Legal Framework & $\begin{array}{l}\text { Political } \\
\text { Stability }\end{array}$ & $\begin{array}{l}\text { Intellectual Property } \\
\text { Rights }\end{array}$ & Overall Grade \\
\hline & $30 \%$ & $30 \%$ & $25 \%$ & $15 \%$ & $100 \%$ \\
\hline USA & A & A- & B- & A- & A- \\
\hline Guatemala & & & & & \\
\hline Mexico & B & C & C & C & C + \\
\hline Costa Rica & C & B- & A & B- & B \\
\hline Panama & B- & B- & D & C + & C + \\
\hline
\end{tabular}

Source: Srinivasan, Mandyam; Theodore Stank, Phillipe-Pierre Dornier, and Kenneth Peterson, (2014) Global Supply Chains: Evaluating Regions on an EPIC Framework - Economy, Politics, Infrastructure, and Competence. New York: McGraw Hill. 
Table 12. Strengths and Weaknesses Summary: Politics Dimension

\begin{tabular}{|c|c|c|}
\hline Grade & Strengths & Weaknesses \\
\hline USA: A- & $\begin{array}{l}\text { Stable, fair, pro-business legal and regulatory framework; } \\
\text { low bureaucracy; low bribery and corruption; low tariff } \\
\text { barriers; low risk of political instability; fair treatment for } \\
\text { FDI; absolute tax rate pro-business; strong intellectual } \\
\text { property rights; strong expenditures on education. }\end{array}$ & $\begin{array}{l}\text { Uncertainty over recent political gridlock; complex tax } \\
\text { code; tax code varies by state; high border security } \\
\text { regulations; complex employment and labor laws; } \\
\text { some political corruption. }\end{array}$ \\
\hline \multicolumn{3}{|c|}{ P P } \\
\hline Mexico: C & $\begin{array}{l}\text { Stable political system; good Lawson books for tax, IP, } \\
\text { but enforcement an issue; good regulations for trade zones } \\
\text { to protect import and re-export (related to maquiladora). }\end{array}$ & $\begin{array}{l}\text { Complex legal and regulatory framework; high levels } \\
\text { of bureaucracy with "irregular payments" often the } \\
\text { norm; high levels of bribery and corruption; complex } \\
\text { tax code and reporting requirements; relatively high } \\
\text { tariff and protection barriers; FDI rules are open but } \\
\text { significant monopoly and oligopoly prevents fair } \\
\text { application of rules; some industries (energy, } \\
\text { telecommunications, freight, transportation) protected } \\
\text { against FDI; good IP laws, but in practice much piracy } \\
\text { and counterfeiting; stiff and complex labor laws. }\end{array}$ \\
\hline Costa Rica: B & $\begin{array}{l}\text { One of the most solid democracies in Latin America with } \\
\text { peaceful and transparent election processes; pro-market } \\
\text { and social policies; good security record; skilled labor } \\
\text { force; legal regulations concerning business are generally } \\
\text { straightforward; low levels of corruption; well-defined } \\
\text { tax code. }\end{array}$ & $\begin{array}{l}\text { Upsurge in drug trafficking and related violent crimes; } \\
\text { struggling to come to terms with the country's ailing } \\
\text { financial situation; recent corruption scandals; } \\
\text { regulatory environment can be complex for foreign } \\
\text { ownership in industries with state-owned firms; } \\
\text { bureaucratic inefficiency; IP rights a concern. }\end{array}$ \\
\hline Panama: $\mathrm{C}+$ & $\begin{array}{l}\text { Generally stable political environment; business-friendly } \\
\text { president and legal system with pro-business agenda; } \\
\text { modern procurement, business ownership, and consumer } \\
\text { protection legislation; modern customs process; flexible } \\
\text { labor laws in Canal Zone and FTZ. }\end{array}$ & $\begin{array}{l}\text { High levels of corruption in judiciary; security issues } \\
\text { and violence rising linked to drug organizations; pro- } \\
\text { business agenda has stoked domestic tension, } \\
\text { generating strong protests; lack of efficient protection } \\
\text { of intellectual property, particularly when it comes to } \\
\text { piracy and counterfeit items; restrictive labor laws } \\
\text { limit hiring, compensation, firing, and flexibility. }\end{array}$ \\
\hline
\end{tabular}

Source: Srinivasan, Mandyam; Theodore Stank, Phillipe-Pierre Dornier, and Kenneth Peterson, (2014) Global Supply Chains: Evaluating Regions on an EPIC Framework - Economy, Politics, Infrastructure, and Competence. New York: McGraw Hill.

Table 13. Scores for the Infrastructure Dimension (30\% of the EPIC Weight)

\begin{tabular}{|l|l|l|l|l|}
\hline & $\begin{array}{c}\text { Transportation } \\
\text { Infrastructure }\end{array}$ & \multicolumn{1}{|c|}{ Energy Infrastructure } & Connectivity & Overall Grade \\
\hline & $50 \%$ & $25 \%$ & $25 \%$ & $100 \%$ \\
\hline USA & A- & B + & B & B + \\
\hline Guatemala & & & & \\
\hline Mexico & B- & C & C & C + \\
\hline Costa Rica & D & B & C + & C- \\
\hline Panama & A- & B & B & B + \\
\hline
\end{tabular}

Source: Srinivasan, Mandyam; Theodore Stank, Phillipe-Pierre Dornier, and Kenneth Peterson, (2014) Global Supply Chains: Evaluating Regions on an EPIC Framework - Economy, Politics, Infrastructure, and Competence. New York: McGraw Hill. 
Table 14. Strengths and Weaknesses Summary: Infrastructure Dimension

\begin{tabular}{|c|c|c|}
\hline Grade & Strengths & Weaknesses \\
\hline USA: B+ & $\begin{array}{l}\text { Good access to commodities; improving energy picture with } \\
\text { Canadian shale oil and natural gas; excellent road, rail, water, } \\
\text { and airport system; internal river system best in the world } \\
\text { although underutilized for domestic transport; good } \\
\text { telecommunications capabilities, leading innovators; leader in e- } \\
\text { commerce for Business-to-Business (B2B) and Business-to- } \\
\text { Consumer (B2C). }\end{array}$ & $\begin{array}{l}\text { Need for expanded capacity and investment } \\
\text { in infrastructure a major challenge for } \\
\text { coming years; air industry troubled, } \\
\text { possibly in need of reregulation; power } \\
\text { distribution extensive but outdated; high- } \\
\text { speed telecommunications lags Europe and } \\
\text { developed Asia; telecommunications } \\
\text { industry fragmented. }\end{array}$ \\
\hline \multicolumn{3}{|l|}{ Guatemala: } \\
\hline Mexico: $\mathrm{C}+$ & $\begin{array}{l}\text { One of the best infrastructures in LATAM, but not up to par with } \\
\text { USA or Canada; air network particularly good; significant } \\
\text { investment in ports and rail to connect to USA, especially } \\
\text { Manzanillo, Lazaro Cardenas, (both Pacific coast) and Veracruz } \\
\text { (Gulf); quality of road, rail, water, and air transport improving } \\
\text { with privatization. }\end{array}$ & $\begin{array}{l}\text { Road, rail, water, air transport, power } \\
\text { distribution, and telecommunications still } \\
\text { not at levels of industrialized world, with } \\
\text { many challenges and barriers; availability } \\
\text { and quality of infrastructure varies greatly } \\
\text { across the country, being generally good in } \\
\text { the central plain and north but poor in the } \\
\text { south. }\end{array}$ \\
\hline Costa Rica: C- & $\begin{array}{l}\text { Strong air cargo system; Pacific and Caribbean/Atlantic port } \\
\text { access; good power distribution, water access, and } \\
\text { telecommunications. }\end{array}$ & $\begin{array}{l}\text { Poor road and rail infrastructure; limited } \\
\text { cargo capacity in seaports. }\end{array}$ \\
\hline Panama: $\mathrm{B}+$ & $\begin{array}{l}\text { Panama Canal; Colón Free Trade Zone; modern } \\
\text { telecommunications and power distribution grid; sufficient road } \\
\text { and rail connectivity between Pacific and Caribbean/Atlantic } \\
\text { ports. }\end{array}$ & $\begin{array}{l}\text { No continuous east-west highway to link } \\
\text { North and South America. }\end{array}$ \\
\hline
\end{tabular}

Source: Srinivasan, Mandyam; Theodore Stank, Phillipe-Pierre Dornier, and Kenneth Peterson, (2014) Global Supply Chains: Evaluating Regions on an EPIC Framework - Economy, Politics, Infrastructure, and Competence. New York: McGraw Hill.

Table 15. Scores for the Competence Dimension (20\% of the EPIC Weighting)

\begin{tabular}{|c|c|c|c|c|c|}
\hline & Labor Relations & Education Levels & $\begin{array}{c}\text { Logistics } \\
\text { Competence }\end{array}$ & $\begin{array}{c}\text { Customs and } \\
\text { Security }\end{array}$ & Overall Grade \\
\hline & $25 \%$ & $25 \%$ & $40 \%$ & $10 \%$ & $100 \%$ \\
\hline USA & A- & A- & $\mathrm{A}$ & $\mathrm{A}$ & $\mathrm{A}$ \\
\hline \multicolumn{6}{|l|}{ Guatemala } \\
\hline Mexico & $\mathrm{C}$ & $\mathrm{C}+$ & $\mathrm{B}$ & $\mathrm{C}+$ & B- \\
\hline Costa Rica & $\mathrm{B}$ & $\mathrm{B}+$ & $\mathrm{C}$ & $\mathrm{C}$ & B- \\
\hline Panama & $\mathrm{C}$ - & $\mathrm{C}-$ & B- & $\mathrm{C}+$ & $\mathrm{C}+$ \\
\hline
\end{tabular}

Source: Srinivasan, Mandyam; Theodore Stank, Phillipe-Pierre Dornier, and Kenneth Peterson, (2014) Global Supply Chains: Evaluating Regions on an EPIC Framework - Economy, Politics, Infrastructure, and Competence. New York: McGraw Hill. 
Table 16. Strengths and Weaknesses Summary: Competence Dimension

\begin{tabular}{|c|c|c|}
\hline Grade & Strengths & Weaknesses \\
\hline USA: A & $\begin{array}{l}\text { Workers are highly productive; working } \\
\text { age population is growing due to Mexican } \\
\text { immigration; education has its detractors, } \\
\text { but in general fares well in education and } \\
\text { training categories, both for labor and } \\
\text { management; unions are weakening } \\
\text { compared to other industrialized nations, } \\
\text { although this varies by region; labor } \\
\text { relations are good, logistics and } \\
\text { transportation among the best in the world. }\end{array}$ & $\begin{array}{l}\text { Overall skilled labor poll is shrinking; some } \\
\text { big problems underlie the education } \\
\text { system; training programs akin to } \\
\text { apprentice programs in Europe are poor or } \\
\text { nonexistent. }\end{array}$ \\
\hline \multicolumn{3}{|l|}{ Guatemala: } \\
\hline Mexico: B- & $\begin{array}{l}\text { Productivity is improving (but still far } \\
\text { below global standards); growing and } \\
\text { young workforce; union membership in } \\
\text { most industries low; government working } \\
\text { to improve training and education. }\end{array}$ & $\begin{array}{l}\text { Productivity lags global average; ensuring } \\
\text { that workers show up has been a huge } \\
\text { problem in the maquiladora industry; } \\
\text { education, training, and managerial skills } \\
\text { far below the global average; shortages of } \\
\text { skilled workers in key industries; logistics } \\
\text { industry lag industrial world. }\end{array}$ \\
\hline Costa Rica: B- & $\begin{array}{l}\text { Skilled labor is readily available; highly } \\
\text { educated and literate; English commonly } \\
\text { spoke; low levels of unionization and good } \\
\text { labor relations; god productivity of labor } \\
\text { and improving; overall logistics service } \\
\text { industry satisfactory (but some issues). }\end{array}$ & $\begin{array}{l}\text { Lack of integration in logistics service } \\
\text { forces companies to deal with multiple } \\
\text { parties, especially when utilizing seaports } \\
\text { (lack of organization). }\end{array}$ \\
\hline Panama: $\mathrm{C}+$ & $\begin{array}{l}\text { Young and growing workforce; fairly well } \\
\text { educated and skilled; Panama Canal zone } \\
\text { employees cannot strike, significant } \\
\text { presence of global third-party logistics } \\
\text { firms making integrated logistics a strength; } \\
\text { strong customer and international shipping } \\
\text { capability. }\end{array}$ & $\begin{array}{l}\text { Organized labor relatively strong; limited } \\
\text { skilled workforce capacity. }\end{array}$ \\
\hline
\end{tabular}

Source: Srinivasan, Mandyam; Theodore Stank, Phillipe-Pierre Dornier, and Kenneth Peterson, (2014) Global Supply Chains: Evaluating Regions on an EPIC Framework - Economy, Politics, Infrastructure, and Competence. New York: McGraw Hill.

Table 17. Summary Assessment of EPIC Attractiveness of Key North and Central American Nations

\begin{tabular}{|c|c|c|c|c|c|}
\hline 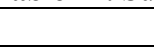 & Economy & Politics & Infrastructure & Competence & Overall Grade \\
\hline USA & $\mathrm{B}+$ & A- & $\mathrm{B}+$ & A & A- \\
\hline \multicolumn{6}{|l|}{ Guatemala } \\
\hline Mexico & $\mathrm{B}+$ & $\mathrm{C}+$ & $\mathrm{C}+$ & B- & B- \\
\hline Costa Rica & $\mathrm{C}+$ & B & C- & B- & $\mathrm{C}+$ \\
\hline Panama & $\mathrm{B}$ & $\mathrm{C}+$ & $\mathrm{B}+$ & $\mathrm{C}+$ & B- \\
\hline
\end{tabular}

Source: Srinivasan, Mandyam; Theodore Stank, Phillipe-Pierre Dornier, and Kenneth Peterson, (2014) Global Supply Chains: Evaluating Regions on an EPIC Framework - Economy, Politics, Infrastructure, and Competence. New York: McGraw Hill. 